Received 07.11.2017 Reviewed 28.03.2018 Accepted 09.04.2018

A - study design

B - data collection

C - statistical analysis

D - data interpretation

$\mathbf{E}$ - manuscript preparation

F - literature search

\section{Contribution to flood risk management by the IRIP method at the level of Gareat EI Taref catchment, Constantine's highlands, North-East of Algeria}

Dali NAOUEL ${ }^{\text {ABCDEF } ₫}$, Derradji ZOUINI ${ }^{\text {AE }}$, Pascal BREIL ${ }^{\text {DE }}$

University Abbes Laghrour, Department of Biology, Khenchela, Algeria; e-mail: dali.naouel@hotmail.fr, zouinid@yahoo.fr, pascal.breil@irstea.fr

For citation: Naouel D., Zouini D., Breil P. 2018. Contribution to flood risk management by the IRIP method at the level of Gareat El Taref catchment, Constantine's highlands, North-East of Algeria. Journal of Water and Land Development. No. 38 p. 95-104. DOI: 10.2478/jwld-2018-0046.

\begin{abstract}
The term flooding is often associated with a stream overflow or a marine flood, runoff- floods is rarely considered, and today suffers from a lack of knowledge and control of the phenomenon. This paper, presents a geographic information system iRIP@-Flooding by Intense Pluvial Runoff (French acronym), which is a new tool to mapping flooding by runoff as a tool for decision-making by mapping runoff flooding in Gareat El Taref catchment (Northeast Algeria), with identifying the area of production, transfer and accumulation of flood.

Us results, we have cards represent the potential of a territory to generate the various hydraulic dynamics of runoff: the runoff production card, the runoff transfer, the runoff accumulation card, the runoff-flooding card.

A visual simulation on the flood risk card indicates that the areas with an important runoff flood risk are the communes of Khenchela Oum El Bouaghi Ain El Beida and F'kirina. Moreover, the roads that join Khenchela with Ain El Beida and with Oum El Bouaghi.

Khenchela city is exposed to a great risk of flooding by runoff, the solution proposed by the authorities and that summarizes by the construction of a canal is not sufficient, because on the one hand the north of the city remains exposed to this risk. On the other hand, a large area of runoff production is located between the canal and the city.

It is probably operating to encourage farmers to introduce certain agricultural practices that are part of a sustainable management of flood risk by runoff.
\end{abstract}

Key words: flood management, flood risk, iRIP, Khenchela, runoff

\section{INTRODUCTION}

Worldwide, among the different types of natural disasters, floods appeared to be the most frequent during the last two decades, two natural disasters on five are floods, which, with 2,480 million people affected, represent more than half of all affected by disasters [TRAN et al. 2011]. Flooding causes about half of all deaths [EM-DAT 2017].
Northern Algeria has experienced a severe drought for nearly 15 years, from 1987 to 2002 . It is followed by a return to a more humid situation since 2003. This return to more abundant precipitation is accompanied by a greater number of extreme rain events (severe storm-rainfall disturbances). These phenomena have been particularly frequent during the last decade, as have the stormy days [NOACEUR et al. 2013]. 
This drought period was followed by series of floods in which the country was not ready and that resulted in loss of human lives and considerable material damage. During the morning of 10 November 2001, more than $130 \mathrm{~mm}$ of precipitation was recorded at Bouzareah and resulted in mudslides, which devastated the Bab-El-Oued district. This disaster caused more than 700 casualties and catastrophic damage [ARGENCE et al. 2006].

As a result of these disasters, the Algerian Ministry of Water Resources and Environment is extending the national water plan which aims to develop a national strategy to fight against floods [AROUA, BEREZOWSKA-AZZAG 2013].

In Algeria the term flooding is often associated with a stream overflow [MOKHTARI et al. 2016] [SKHAKHFA, OUERDACHI 2016], a marine flood or dam break flood [BoUCHEHED et al. 2017]. Floods caused by intense overland runoff are rarely considered and today suffers from a lack of knowledge and control of the phenomenon.

Flooding by intense runoff has received little attention from hydrologist because the related processes are soil losses, mudflows, landslides, erosion and deposits of earth material or human infrastructures. These consequences mostly relate to geotechnical and cropland management services when they are recurrent and integrated in a risk management strategy. However very heavy rainfall can enlarge the usual local effects and cause damages to human population like this occurred in Colombia (Mokoa city, April 2017) with more than 300 died or in January 2018 in California (Montecito city) with 13 people died. In these cases the question is no more where the local effects can occur but where they would probably spread downstream in case of exceptional heavy rainfalls. In most of the case, it is noted that catastrophic consequences are related to rainfall amounts that overpass $100 \mathrm{~mm}$ in some hours.

This study focuses for the first time in Algeria, on runoff flooding outside the hydrographic network and their mapping with indicator of intense pluvial runoff (Fr. Indicateur de Ruissellement Intense Pluvial IRIP) method [DEHOTIN et al. 2015a; LAGADEC et al. $2016 \mathrm{~b}$ ]. It is a geomatics method, which produces cards of a territory spatial susceptibility to generate, to transfer and to accumulate intense surface runoff [LAGADEC et al. 2016b].

This choice can be explained by the fact that the study area, which is the Gareat El Taref catchment, has topographic [BENABBAS 2006], soil [ZOUAOUI 2008], and land use characteristics that favour overland runoff. However, at the same time there is no published study in this topic.

In addition, the main agglomerations in the catchment (Khenchela, Oum El Bouaghi, and Ain El Beida) are located at the mountains foothills that limit the catchment, which exposes them to the flood risk by runoff.
A better management of a natural risk requires a good knowledge of the later and the identification of where the preventive actions would be most effective.

This study has therefore two main objectives:

- mapping of the hazard and the flood risk by runoff at the Gareat El Taref catchment using the iRIP@ software derived from the "Intense Pluvial Runoff Indicator IRIP" method;

- putting a focus on the city of Khenchela in terms of flood risk management by runoff.

\section{METHODS}

\section{STUDY AREA}

The Gareat El Taref basin is located in the northeastern part of Algeria; at the extreme East of the high steppe plains between the Tellian Atlas in the North and the Saharan Atlas in the South (Aurès massif).

The catchment is part of all the basins of the Constantine's highlands according to the agency of the basins (Fig. 1). It covers an area of $2432 \mathrm{~km}^{2}$. It is located between latitude $35^{\circ} 22^{\prime}$ and $35^{\circ} 56^{\prime} \mathrm{N}$ and longitudes $6^{\circ} 49^{\prime}$ and $7^{\circ} 34^{\prime} \mathrm{E}$. The center is marked by an endorheic depression (Gareat) better known under the name sabkha (salt lake) and covers an area of $200 \mathrm{~km}^{2}$.

Gareat El Taref catchment is dominated by high plains strewn with chott depressions (Gareat El Taref), with an altitude of about $830 \mathrm{~m}$, the latter extending over $20 \mathrm{~km}$ long and $15 \mathrm{~km}$ wide of which only $1 / 4$ is flooded. All around, there are satellites chotts merging with that of El Taref during major floods. The perimeters of this salt lake are characterized by a flat level. The massifs that frame the basin exceed $2000 \mathrm{~m}$. The southern and northern borders of the basin are marked by relatively large inclinations; because of tectonic activity affecting these regions, allowing a greater surface flow [GUIRAUD 1973].

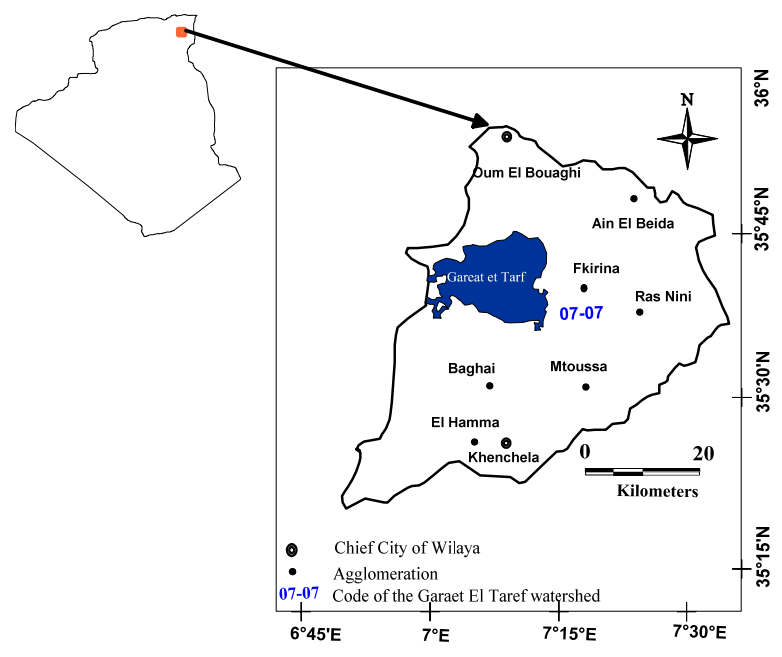

Fig. 1. Geographical location of the study area; source: own elaboration 
Two types of climate characterize the Gareat El Taref sub-basin; the South is influenced by cold and humid air drafts coming from the Aures where altitude exceeds $2000 \mathrm{~m}$, enjoys a temperate climate. The North, which is a vast plain where the altitude drops to less than $850 \mathrm{~m}$, is covered by a semi-arid climate.

The majority of the wadis are endoric; they flow towards the salt lakes. Wadi Gueiss is the only permanent Wadi in the catchment; it leaves the Jebel Noughiss and flows into the Gareat El Taref under the name of Wadi Marouf. Temporary wadis drain the South of the basin while Faids (flooded plain) characterize the North.

Given the absence of observations of flood at the described catchment, and in order to have an idea of the probability of such events. We used an empirical formula for estimating maximums daily flows, we used Possenti formula [REMENIERAS 1976], because this method was evaluated with measures values by hydrometric stations existing in semi-arid zone in Algeria [SGHARA 2013].

$$
Q_{\max f \%}=\frac{\mu P J_{\max , p \%} \cdot A_{b v}}{L_{p}}
$$

Where: $Q_{\max f \%}=$ maximum daily flow corresponding to a given return period $\left(\mathrm{m}^{2} \cdot \mathrm{s}^{-1}\right) ; \mu=$ coefficient between 700-800 (we take $\mu=750$ ); $P J_{\max , p \%}=$ maximum daily rain corresponding to a given return period (m); $L_{P}=$ length of the main through $(\mathrm{km}) ; A_{b v}=$ catchment area $\left(\mathrm{km}^{2}\right)$.

A statistical analysis was carried out to assess the annual maximum daily precipitation measured in Foum El Gueiss station between 1970 and 2006.

The Gareat El Taref basin, can therefore be confronted with floods that are manifested by heavy rain (92 to $102 \mathrm{~mm}$ ), characterized by flows between 3442 to $3819 \mathrm{~m}^{3} \cdot \mathrm{s}^{-1}$, for a period of return of the order 50 and 100 years old (Tab. 1).

Table 1. Estimated return levels at selected return period of the annual maximum daily rainfall and annual maximum daily discharges for Foum El Gueiss station (1970-2006)

\begin{tabular}{|c|c|c|}
\hline $\begin{array}{c}\text { Return period } \\
\text { years }\end{array}$ & $\begin{array}{c}\text { Annual maximum } \\
\text { daily rainfall, } \mathrm{mm}\end{array}$ & $\begin{array}{c}\text { Annual maximum } \\
\text { daily discharge } \\
\mathrm{m}^{3} \cdot \mathrm{s}^{-1}\end{array}$ \\
\hline 100 & 102 & 3819 \\
\hline 50 & 92 & 3442 \\
\hline 20 & 78 & 2939 \\
\hline 5 & 57 & 2145 \\
\hline
\end{tabular}

Source: own elaboration.

\section{THE INDICATOR OF INTENSE PLUVIAL RUNOFF (IRIP) METHOD}

An inventory [JAILLET et al. 2012] of the methods and cartographic transcripts of intense runoff in flood prevention plans in France concluded that runoff modelling is done three ways.

- Using field expertise by geomorphologist - this approach is well adapted for the analysis of a floodplain extension but has very low potential for past event that involved mudflows.

- Rain-flow modelling which requires data particularly accurate and great expertise; it is then well adapted to already identified risk situation where an operational response is expected.

- Scoring methods result from the hypothesis that convergence of indicators in favour of a given response increases its probability or its potential. They are well adapted in a first level of analysis to identify the potential for risk situations because they can be used on large territory if necessary data are available. From this inventory it was concluded the necessity to develop a national reference tool based on a score method as to address the existing weak points: there is no detailed method designed to identify where intense runoff initiates, where it goes through, and where it can impact. The method should be kept ready simple to implement and understand as to allow for rapid checking of study results by experts on request. The validation of the method and of its indicators relies on the capacity of the method to detect already impacted situations because there are no monitoring of intense overland runoff, this in comparison to river gauge stations that are used to model river flood regimes and inundations.

The IRIP method was developed by IRSTEA [Bonnet 2012; DeHOtin, BREIL 2011b; DeHOTIN et al. 2015a; LAGADEC et al. 2016b].

Following a partnership, the iRIP@ software is a GIS (geographic information system) which was designed in 2012 by French National Railway Company.

In this context, runoff is defined as "a circulation of water on the soil surface, which takes a diffuse appearance on lands having a homogeneous topography and which concentrates when encountering topographical depressions".

The IRIP method is based on the decomposition of the intense runoff into three steps, from using different layers of geographic information. It provides a spatial distribution of the potential for intense runoff without considering characteristics of heavy rainfalls. This is because heavy rainfall can occur everywhere in a territory and that ground conditions are known to play a determinant role in the genesis and fate of intense overland runoff. This makes the method applicable to any type of climate [LAVERNE 2013]. The three steps correspond to cards presenting the (Fig. 2). - production areas (contributory zones) where the ground conditions permit the formation of a surface water blade and its motion;

- natural or artificial transfer axes that promote the flow of runoff downstream;

- areas of accumulation of runoff, either behind an obstacle, or by slowing down when the slope is less strong or by storage in a depression [DEHOTIN et al. 2015b]. 


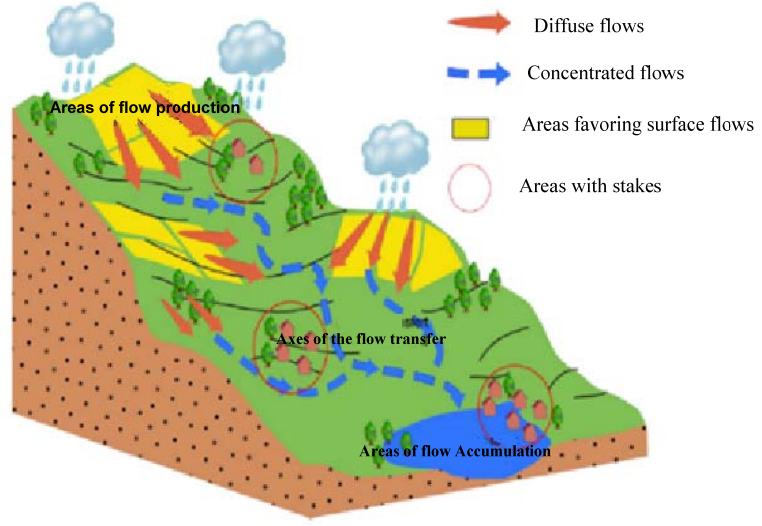

Fig. 2. Areas of production, transfer and accumulation of runoff at the scale of a catchment; source: BONNET [2012]

Table 2. List of the 5 factors per card used to create the 3 indicators of intense pluvial runoff (IRIP) in the form of the cards of generation, transfer and accumulation susceptibility, with the criteria of favourability for each indicator

\begin{tabular}{|c|c|c|}
\hline $\begin{array}{l}\text { IRIP } \\
\text { cards }\end{array}$ & Indicators & Values \\
\hline \multirow{5}{*}{ 宽 } & soil permeability & $\begin{array}{l}0: \text { high permeability } \\
1: \text { low permeability }\end{array}$ \\
\hline & soil thickness & $\begin{array}{l}\text { 0: thick soil } \\
1: \text { thin soil }\end{array}$ \\
\hline & soil erodibility & $\begin{array}{c}0: \text { low erodibility } \\
1: \text { high erodibility }\end{array}$ \\
\hline & topography & $\begin{array}{l}\text { 0: slope }<\mathrm{t} 1 \text { AND topographic } \\
\text { index }<\mathrm{t} 2 \\
1: \text { slope }>\mathrm{t} 1 \text { OR topographic } \\
\text { index }>\mathrm{t} 2\end{array}$ \\
\hline & land use & $\begin{array}{l}0: \text { infiltrative surfaces } \\
1: \text { impervious surfaces }\end{array}$ \\
\hline \multirow{5}{*}{ 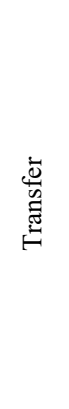 } & $\begin{array}{l}\text { upstream generation } \\
\text { susceptibility }\end{array}$ & $\begin{array}{l}0 \text { : low upstream generation sus- } \\
\text { ceptibility } \\
\text { 1: high upstream generation sus- } \\
\text { ceptibility }\end{array}$ \\
\hline & slope & $\begin{array}{l}0: \text { slope }<\mathrm{t} 1 \\
1: \text { slope }>\mathrm{t} 1\end{array}$ \\
\hline & break of slope & $\begin{array}{l}0: \text { concave break of slope } \\
1: \text { convex break of slope }\end{array}$ \\
\hline & catchment capacity & $\begin{array}{l}0 \text { : low Horton form factor } \\
\text { 1: high Horton form factor }\end{array}$ \\
\hline & artificial linear axes & $\begin{array}{l}0: \text { no linear axes } \\
1: \text { presence of linear axes }\end{array}$ \\
\hline \multirow{5}{*}{ 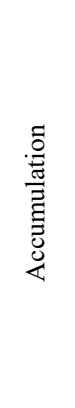 } & $\begin{array}{l}\text { upstream generation } \\
\text { susceptibility }\end{array}$ & $\begin{array}{l}0 \text { : low upstream generation sus- } \\
\text { ceptibility } \\
\text { 1: high upstream generation sus- } \\
\text { ceptibility }\end{array}$ \\
\hline & slope & $\begin{array}{l}0: \text { slope }>\mathrm{t} 1 \\
1: \text { slope }<\mathrm{t} 1\end{array}$ \\
\hline & break of slope & $\begin{array}{l}0: \text { convex break of slope } \\
1: \text { concave break of slope }\end{array}$ \\
\hline & topographic index & $\begin{array}{l}\text { 0: Topographic index }<\mathrm{t} 2 \\
\text { 1: Topographic index }>\mathrm{t} 2 \\
\end{array}$ \\
\hline & flow accumulation & $\begin{array}{l}0: \text { low flow accumulation } \\
\text { 1: high flow accumulation }\end{array}$ \\
\hline
\end{tabular}

Source: LAGADEC et al. [2016b].

The IRIP method proposes a spatial diagnostic of the intense runoff hazard, at geomatics base, from the identification of natural or artificial areas of production, accumulation and transfer.
This method has been developed for a multi-scale diagnosis. It can therefore be used for local or regional studies depending on the digital elevation model (DEM) input data resolution [BONNET et al. 2013] that can range from tens of meters to one meter.

Each hydraulic dynamics is characterized by five factors. These are treated according to a principle of binary scores (favourable: $1 /$ unfavourable: 0 ) which accumulated, produce a card with 6 levels (from 0 to 5 ) of potential to generate each of the 3 processes (Tab. 2).

The IRIP method calculates indicators from a series of ground factors which roles on the overland runoff have been largely documented [DEHOTIN, BREIL 2011a]. Excepted on impervious areas, rainfall infiltration predominates along a year on overland runoff which requires specific conditions at ground and (or) of rainfall characteristics to occur. To only consider response to heavy rainfall event, the method uses dedicated thresholds of its indicators. For example, deep and permeable soils will not be in favour of intense runoff, while a shallow soil will be. The soil thickness limit was chosen to $0.3 \mathrm{~m}$, which correspond to a water capacity of $80-120 \mathrm{~mm}$ on average. Default thresholds can be changed by the operator as to adapt to local conditions but initial thresholds intends to provide a good gradation of the intense overland runoff potential on large territory of several thousand of squared kilometers. Detailed description of the method is given in DEHOTIN et al. [2015b] and LAGADEC et al. [2016b].

\section{THE INPUT DATA FOR MODELLING ON IRIP@}

The input data required to obtain the iRIP@ cards are the following three layers of information.

- Digital elevation model (DEM) provided by the United States Geological Survey from the Shuttle Radar Topography Mission [USGS 2016] with a square mesh resolution of $30 \mathrm{~m}$ (Fig. 3a). The topographic variable acts, as a function of its local characteristics, both on production and on transfer or accumulation of runoff.

At the slope factor, it is also important to add the shape of the drained areas (Gravelius compactness index). The compactness index will play on the homogeneity of the concentration time distribution in a drained area. The more homogeneous it is, the more the overland runoff will concentrate rapidly and cumulate to increase the overland flow, in opposition to the elongated forms [BENDJOUDI, HUBERT 2002].

- Land use (Fig. 3b). This is the vector version of the land use card of Algeria carried out by the Food and Agriculture Organization of the United Nations [FAO 2016].

- Soil: a soil card in vector format is plotted on QGIS (Fig. 3c) from the ground card of Tebessa Sheet N.I. 32-N.O in 1/500 000. This card was taken from the European soil data center [ESDAC 2016], the analysis and the classification of the soil 
a)

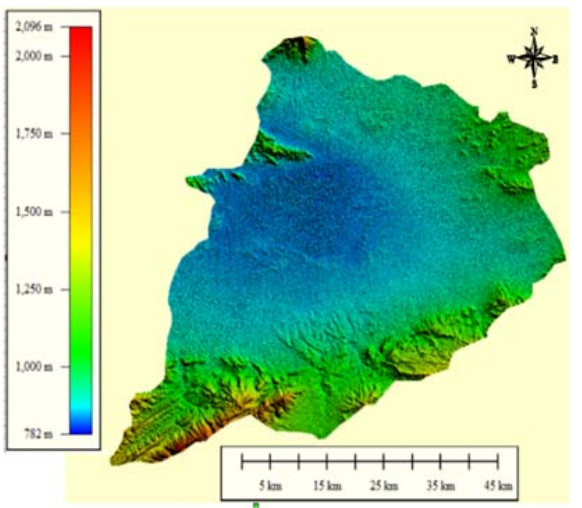

b)

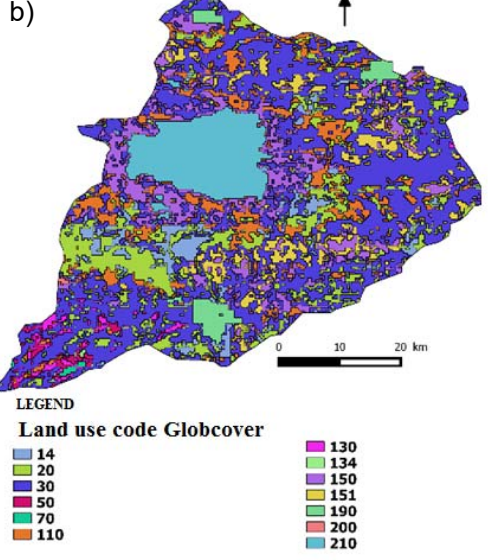

c)

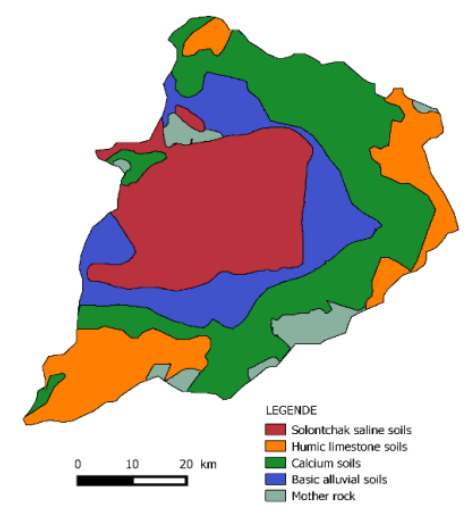

Fig. 3.iRIP@ input cards for the Gareat El Taref catchment: a) digital elevation model [USGS 2016]; b) land use [FAO 2016], c) soil [ESDAC 2016]

is made according to the soil study of Constantine's highlands [ZOUAOUI 2008].

Before the introduction of the data on IRIP@, a coding of the soil and land use card is carried out (Tabs. 3, 4).

Table 3. Indicators of intense pluvial runoff's (IRIP's) codes of soils mapping units (SMU), in the Gareat El Taref catchment area

\begin{tabular}{|l|c|c|c|}
\hline \multirow{2}{*}{ Soils mapping units } & \multicolumn{3}{|c|}{ Code for IRIP@ } \\
\cline { 2 - 4 } & $\begin{array}{c}\text { soil } \\
\text { erodibility }\end{array}$ & $\begin{array}{c}\text { soil } \\
\text { permeability }\end{array}$ & $\begin{array}{c}\text { piezometric } \\
\text { level }\end{array}$ \\
\hline Solontchak saline soils & 1 & 1 & 1 \\
\hline $\begin{array}{l}\text { Humiferous limestone } \\
\text { soil }\end{array}$ & 1 & 1 & 0 \\
\hline Calcium soils & 1 & 1 & 0 \\
\hline Basic alluvial soils & 1 & 0 & 0 \\
\hline parent rock & 0 & 1 & 0 \\
\hline
\end{tabular}

Source: own elaboration.

Table 4. Indicators of intense pluvial runoff's (IRIP's) codes of land use in the Gareat El Taref catchment area

\begin{tabular}{|c|c|c|}
\hline Value & Label & $\begin{array}{c}\text { Code } \\
\text { for } \\
\text { IRIP@ }\end{array}$ \\
\hline 14 & rainfed croplands & 1 \\
\hline 20 & $\begin{array}{l}\text { mosaic cropland (50-70\%) / vegetation (grassland/ } \\
\text { shrubland/forest) }(20-50 \%)\end{array}$ & 1 \\
\hline 30 & $\begin{array}{l}\text { mosaic vegetation (grassland/shrubland/forest) } \\
(50-70 \%) \text { / cropland }(20-50 \%)\end{array}$ & 1 \\
\hline 50 & closed $(>40 \%)$ broadleaved deciduous forest $(>5 \mathrm{~m})$ & 0 \\
\hline 70 & $\begin{array}{l}\text { closed }(>40 \%) \text { needleleaved evergreen forest } \\
(>5 \mathrm{~m})\end{array}$ & 0 \\
\hline 110 & $\begin{array}{l}\text { mosaic forest or shrubland }(50-70 \%) / \text { grassland } \\
(20-50 \%)\end{array}$ & 1 \\
\hline 130 & $\begin{array}{l}\text { closed to open }(>15 \%) \text { (broadleaved or needle- } \\
\text { leaved, evergreen or deciduous) shrubland }(<5 \mathrm{~m})\end{array}$ & 0 \\
\hline 134 & $\begin{array}{l}\text { closed to open }(>15 \%) \text { broadleaved deciduous } \\
\text { shrubland }(<5 \mathrm{~m})\end{array}$ & 0 \\
\hline 150 & sparse $(<15 \%)$ vegetation & 0 \\
\hline 151 & sparse $(<15 \%)$ grassland & 0 \\
\hline 190 & $\begin{array}{l}\text { artificial surfaces and associated areas (urban areas } \\
>50 \% \text { ) }\end{array}$ & 1 \\
\hline 200 & bare areas & 1 \\
\hline 210 & water bodies & 1 \\
\hline
\end{tabular}

Source: own elaboration.

\section{THE CARDS CALCULATED BY IRIP@}

iRIP@ produces main cards that are: the card of the runoff production sensitivity, the card of the runoff transfer sensitivity and the card of the runoff accumulation sensitivity. The production card enters into the calculation of the other two cards (Fig. 4).

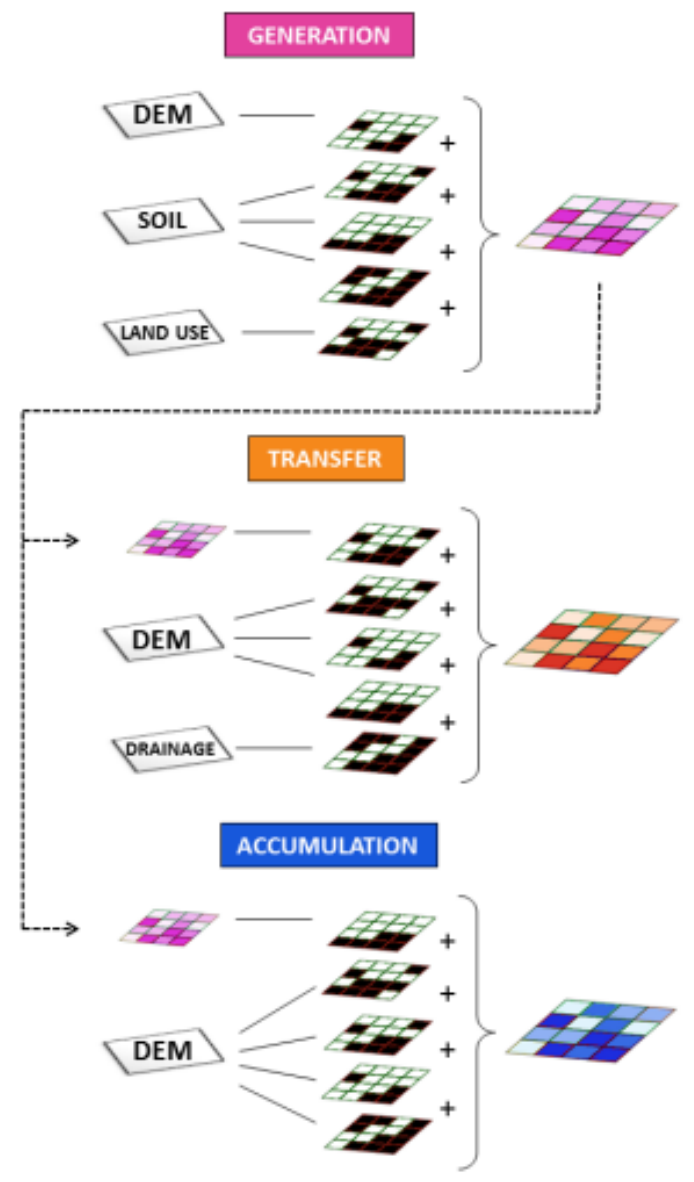

Fig. 4. Scheme of the indicators of intense pluvial runoff's (IRIP's) method and the combination of input data and of the card of generation to produce cards of surface runoff generation, transfer and accumulation susceptibility on a six level scale, from 0 to 5 ; DEM = digital elevation model; source: LAGADEC et al. [2016a] 
These cards result from $15(3 \times 5)$ other intermediate cards which are the cards of the runoff factors used for the calculation of the main cards.

Levels of runoff susceptibility in production transfer and accumulation cards range from 0 to 5 with 0 for no effect at 5 for maximum effect. Indeed, each card results from the sum of the five factor cards that make it up. Each factor card is coded in 0 and 1 to indicate that the factor is active or not in a mesh of the card.

\section{RESULTS AND DISCUSSION}

\section{CARDS CALCULATED BY INDICATORS OF INTENSE PLUVIAL RUNOFF (IRIP)}

\section{The runoff production card}

Study Figure 5, which presents the sensitivity levels of the different parts of the basin to produce runoff. We can distinguish nuances of colours in the slopes with very strong sensitivities on the mountainous edge of the basin as well as in the level of the depression occupy the center of the basin. For a flood risk management perspective, it is important to clearly identify these areas, because some actions taken at this level can help to limit the intensity of the hazard related to runoff.

- Increase soil infiltration and retention. If infiltration proves impossible, rainwater can be stored temporarily and discharged more slowly by hydraulic structures.

- Installing a water buffer system means retaining as much rainwater as possible. Wetlands are buffer zones that can both slow runoff, increase infiltration, recharge groundwater, and increase biodiversity and natural ecosystem services such as self-purification of farm fertilizers and pesticides. Wetlands can also produce animal and plant biomass.

\section{The cardof the runoff transfer}

The card of Figure 6 identifies the transfer axes. The zones with high transfer sensitivity correspond to:

- the production areas bordering the basin;

- the depression occupied by the saline lake in the center of the basin, this is explained by the fact that the bottom of the latter is not perfectly flat, which does not correspond to the conventional definition of the sabkha;

- the transfer axes that correspond to the roads and rivers have been perfectly represented.

- the axes of transfer can be problematic; there are also erosive axes responsible for the mudflows that accompanying runoff flooding; the fact that the transfer axes are fed with high productions indicates a high risk of muddy flows;

- the preventive management mode on these axes must act on the slowing of the runoff speed; for example crops on the terrace or staircase; it is a costly technique, beneficial to farmers, soil conservator, adapts well to mountainous regions and effectively curbs runoff on slopes with a pronounced slope.

\section{The runoff accumulation card}

The susceptibility card of surface runoff accumulation (Fig. 7) shows that the basin has a high sensitivity to accumulate runoff except for mountainous areas in contrast to the card of transfer. The sabkha is not distinguishable from the rest of the watershed. This is justified by the fact that the iRIP calculations are made according to a drainage plan that is calculated in relation to the topography of the study area. Horizontal surfaces such as lacs are areas without flow and that explain why these areas are not represented with large number of strong pixels in card of susceptibility to surface runoff accumulation. Only area of concave break of slopes located on the edge of horizontal topographic zones will delineate the area of accumulation runoff.

These are the factors favourable to the accumulation calculated and not the build itself.

\section{FLOODING AND FLOOD RISK BY RUNOFF}

The runoff-flooding card indicates that the areas of the basin have an important ability to be flooded and / or to undergo mudflows (Fig. 8).

Strong and very strong pixels of the runoff-flooding specially mark:

- the depression that stakes the center of the basin and a large bung that surrounds it on the east and south side;

- agglomerations located at the foot of the mountains.

Areas that may be problematic or at risk are those where runoff hazard crosses high-stakes areas. In this study, we consider that the problem areas are urban and rural agglomerations as well as roads.

A visual simulation on the flood risk card indicates that the areas with an important runoff flood risk are the communes of Khenchela Oum El Bouaghi Ain El Beida and F'kirina. Moreover, the roads that join Khenchela with Ain El Beida and with Oum El Bouaghi.

\section{VALIDATION OF THE FLOOD RISK CARD IRIP@}

There are no published studies on runoff flooding at the Gareat El Taref watershed, for the compared to our cartography, all the studies made concern internal documents. A project to protect the city of Khenchela against flooding is underway; it is an open channel for the collection of runoff water.

A focus on Khenchela city with a mapping overlay obtained by iRIP and the planned channel will allow analysing and comparing the results of the iRIP mapping with the location of this channel. 


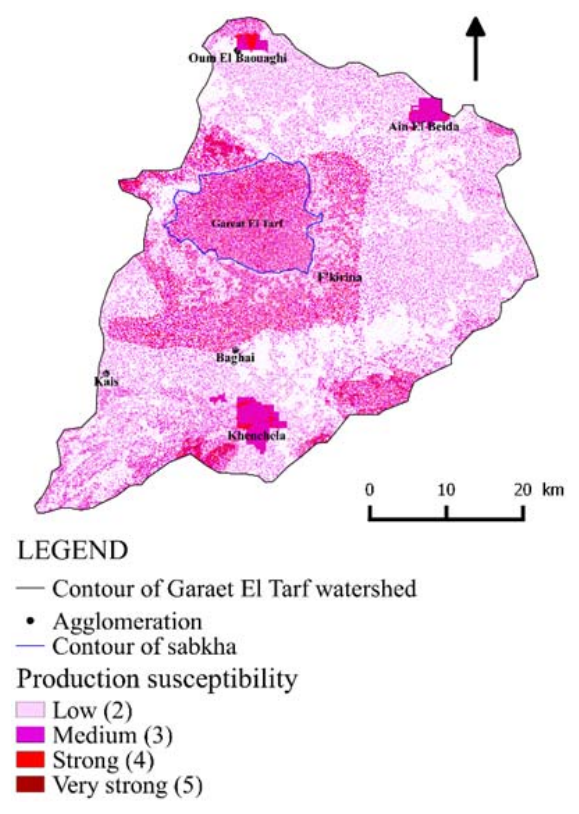

Fig. 5. The indicators of intense pluvial runoff's (IRIP's) card of susceptibility of the Gareat El Taref catchment to surface runoff generation; source: own elaboration

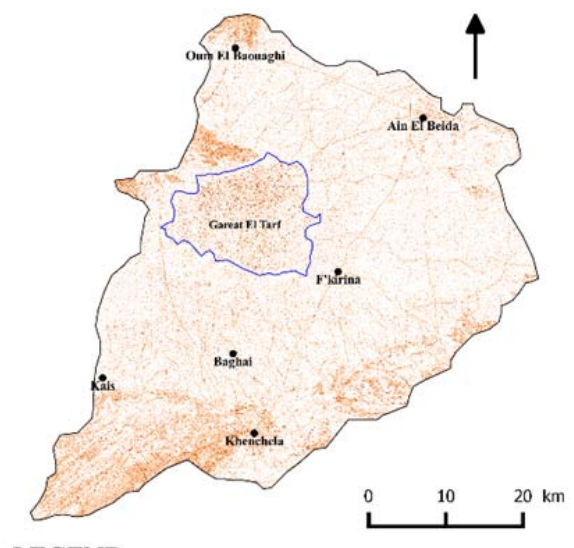

LEGEND

- Contour of Garaet El Tarf watershed

- Agglomeration

- Contour of sabkh

Transfer susceptibility

$\square$ Low (2)

Medium (3)

Strong (4)

Very strong (5)

Fig. 6. The indicators of intense pluvial runoff's (IRIP's) card of susceptibility of the Gareat El Taref catchment

to surface runoff transfer; source: own elaboration

The agglomeration of Khenchela is located south of the Gareat El Taref basin at the foothills of the Ras Serdoun massif and is the subject of a major flood protection project.

The project involves constructing an open channel at the foothills of the Ras Serdoune massif to evacuate the water coming from it to Wadi Frenguel which crosses the southern part of the city and joins Wadi Baghai bordering the latter on the east side (Fig. 9).

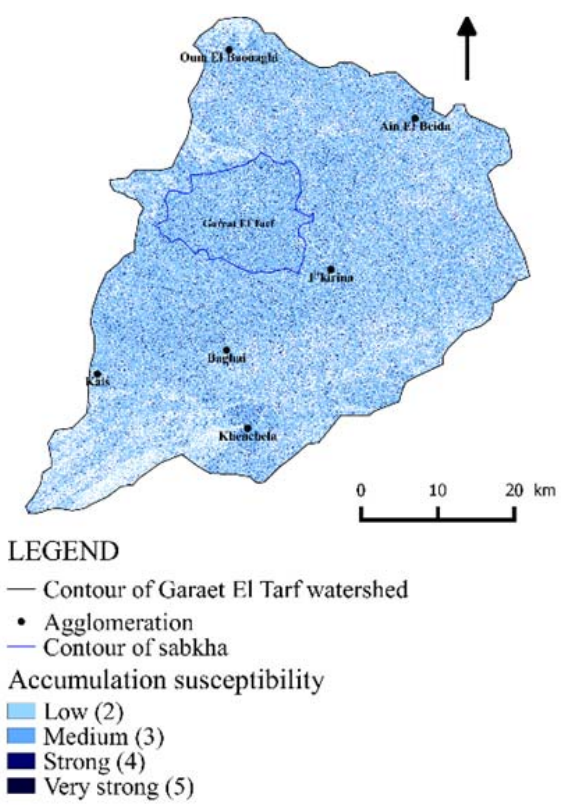

Fig. 7. The indicators of intense pluvial runoff's (IRIP's) card of susceptibility of the Gareat El Taref catchment to surface runoff accumulation; source: own elaboration

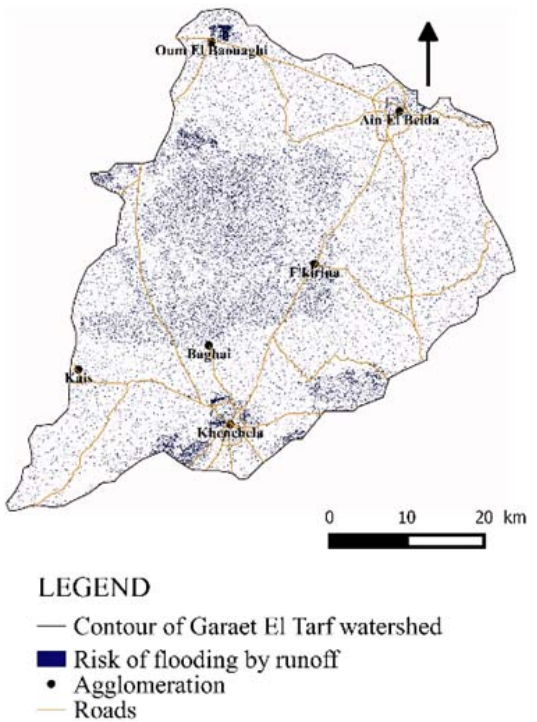

Fig. 8. Card of risk flooding by runoff at Gareat El Taref catchment; source: own elaboration

We analysed the effectiveness of this project as the method of flood risk management at the level of the city of Khenchela as follows:

- reposition the channel on the superimposed flood risk card with the runoff production card by cutting the whole area into a catchment;

- the cards of flood hazard and runoff producing areas, can be used as a support either to set up another channel at the foothill of the northern flank of the Ras Serdoun massif; or to choose the productive zones on which it is possible to act with a view to changing agricultural practice or to work on the mountainous part to curb runoff. 


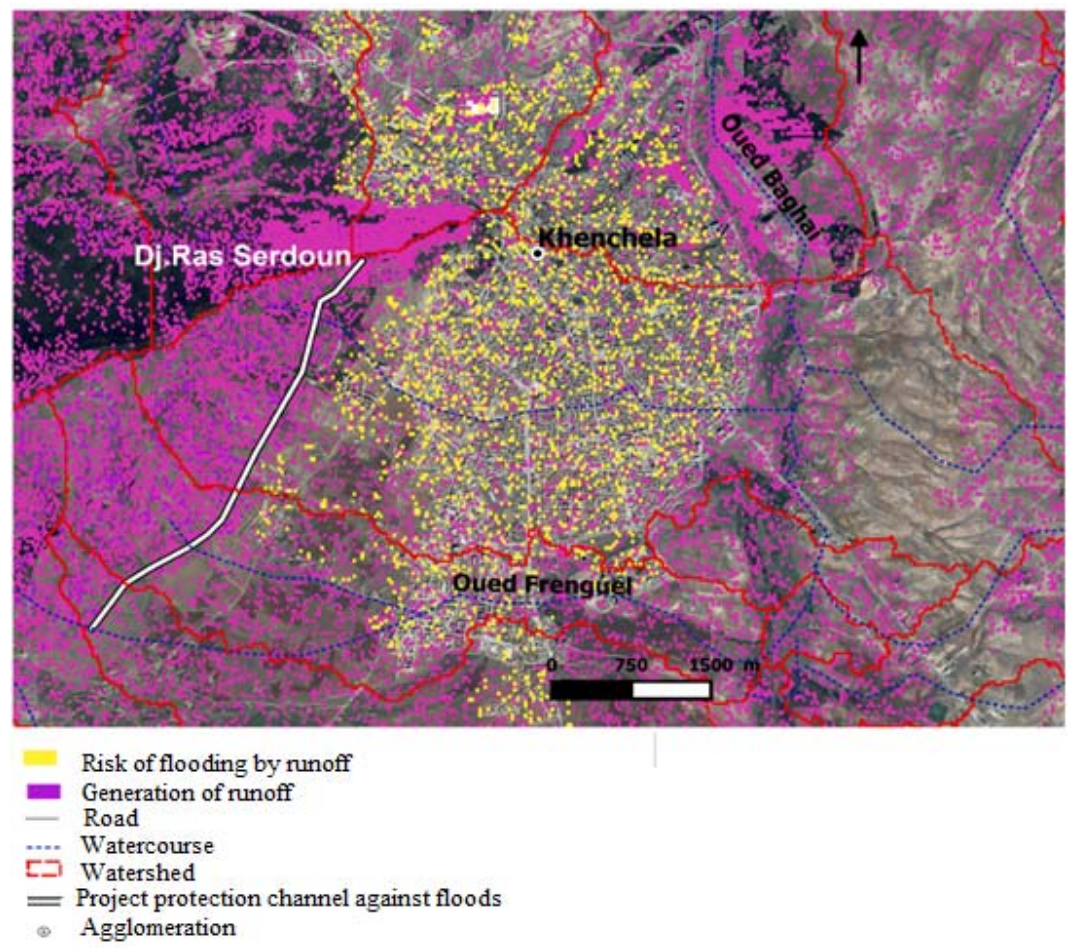

Fig. 9. Risk of flooding by runoff in the Khenchela agglomeration; source: own elaboration

\section{CONCLUSION AND PERSPECTIVES}

The study and the mapping of hazard and risk of flooding by runoff over a large catchment area allows a more global vision of producing, transferring and accumulating areas of runoff, which makes the proposed solutions more efficient and sustainable.

The watershed has a large capacity to accumulate runoff water. The production areas bordering the basin and urban areas are by definition considered impervious and they appear as very productive areas for the intense overland runoff. The roads as axes of transfer can be problematic.

The agglomerations located at the mountains foothills or near of the sabkha are subject to the risk of flooding by runoff. The open channel at the foothills of the Ras Serdoune massif will be able to act effectively to reduce partially the flood risk runoff on the city of Khenchela; it is an obstacle to the runoff water coming from the head of the catchment, which covers the latter. However, a large run-producing area is located between the channel and the city of Khenchela. The evacuation channel will not protect the northern part of the city since it is under another catchment.

To evaluate the effectiveness of the iRIP (French acronym of Intense Pluvial Runoff) method, it is necessary to compare the resulting maps with flooding incidents that already occurred at the study area or in the region. There is no organization for the census the damages caused by this type of floods in general and nor in Algeria. Therefore, to crossbreed the zones at risk of flooding with iRIP cards it is necessary to car- ry out field investigations and to record impacted zones after disasters.

Given the agricultural vocation of the Gareat El Taref basin, it is probably operating to encourage farmers to introduce certain agricultural practices that are part of a sustainable management of flood risk by runoff.

It will be interesting to check whether the resolution of the digital terrain model will have an influence on the iRIP card quality (production, transfer and accumulation).

\section{REFERENCES}

Argence S., Lambert D., Richard E., Sohne N., Chaboureau J., Crepin F., Arbogast P. 2006. High resolution numerical study of the Algiers 2001 flash flood: sensitivity to the upper-level potential vorticity anomaly. Advances in Geosciences. Vol. 7 p. 251-257.

Aroua N., BerezowsKa-AzZAG E. 2013. Le risque intrinsèque à la gestion locale des risques liés à l'eau en Algérie [The intrinsic risk to local management of water risks in Algeria] [online]. Revue Géographique de l'Est. Vol. 53. Iss. 1-2. [Access 30.10.2017]. Available at: https://journals.openedition.org/rge/4628

BenabBas C. 2006. Evolution Mio-Plio-Quaternaire des bassins continentaux de l'Algérie Nord orientale: apport de la photogeologie et analyse morphostructurale [Mio-Plio-Quaternary evolution of continental-rate basins of eastern North Algeria: contribution of photo-geology and morphostructural analysis]. PhD Thesis. Constantine. Univ. Mentouri pp. 253.

Bendjoudi H., HuberT P. 2002. Le coefficient de compacité de Gravelius: analyse critique d'un indice de forme des bassins versants [The Gravelius compactness 
coefficient: critical analysis of a watershed shape index]. Hydrological sciences. Vol. 47 p. 921-930.

BONNET S. 2012. Cartographie des zones potentielles de production ou d'accumulation du ruissellement de surface en région cévenole [Mapping of potential areas of production or accumulation of surface runoff in the Ce-Venole region]. MSc Thesis. Lyon, France. IRSTEA pp. 64

Bonnet S., Poulard C., Breil P. 2013. Cartographie de l'aléa ruissellement - Inventaire des éléments de validation [Mapping of runoff hazard - Inventory of validation elements]. Lyon, France. IRSTEA pp. 118.

Bouchehed H., Mihoubi M.K., Derdous O., DJemili L. 2017. Evaluation of potential dam break flood risks of the cascade dams Mexa and Bougous (El Taref, Algeria). Journal of Water and Land Development. No. 33 p. 39-45. DOI 10.1515/jwld-2017-0017.

DeHOTIN J., BREIL P. 2011a. IRIP project: Research bibliographic report on surface runoff mapping (Literature review). Lyon, France. IRSTEA pp. 120.

Dehotin J., BREIL P. 2011b. Technical report of the IRIP project: mapping the flooding by runoff. Lyon, France. IRSTEA pp. 101.

Dehotin J., Breil P., Braud I., De Lavenne A., Lagouy M., SARRAZIN B. 2015a. Detecting surface runoff location in a small catchment using distributed and simple observation method. Journal of Hydrolgy. Vol. 525 p. 113-129.

Dehotin J., Chazelle B., Laverne G., Hasnaoui A., LAmBert L., Breil P., Braud I. 2015b. Applying runoff mapping method IRIP for flooding risk analysis on railway infrastructure. Houille Blanche. Vol. 6 p. 56-64.

EM-DAT 2017. International disaster database EM-DAT [online]. The OFDA/CRED. [Access 1.11.2017]. Available at: http://www.emdat.be/database

ESDAC 2016. Carte des Sols d'Algérie. Tébessa [Card of the Algerian Soils. Tebessa] [online]. Feuille N.I. 32N.O. European Soil Data Centre. [Access 17.01.2016]. Available at: http://esdac. jrc.ec.europa.eu/content/cartedes-sols-dalg\%C3\%A9rie-t $\%$ C3\%A9bessa-feuille-ni32-no

FAO 2016. Land cover of Algeria - Globcover Regional [online]. Food and Agriculture Organization of the United Nations / GeoNetwork. [Access 20.11.2016]. Available at: http://www.fao.org/geonetwork/srv/en/ main.home?uuid=0e958049-2a0a-4935-83c8af78626068fc

GUIRAUD R. 1973. Evolution post-Triasique de l'Avant pays de la chaine alpine en Algérie d'après l'étude du bassin du Hodna et des régions voisines [Post-Triassic Evolution of the Before-Country of the al-pine Chain in Algeria Based on the Study of the Hodna Basin and Neighboring Regions]. PhD Thesis. Univ. Nice pp. 270.

Jaillet C., Poulard C., Breil P. 2012. Synthèse des méthodes de cartographie des inondations par ruissellement en France (au sens de la Directive Inondation) Convention "prévention des inondations" [Summary of methods for mapping runoff floods in France (in the meaning of the Flood Directive) - Flood Prevention Convention]. Lyon. IRSTEA.
Lagadec L.-R., Breil P., Chazelle C., Braud I., Moulin L. 2016a. Use of post-event surveys of impacts on railways for the evaluation of the IRIP method for surface runoff mapping. 3rd European Conference on Flood Risk Management. Vol. 7 \#10005 pp. 12. DOI 10.1051/e3sconf/20160710005.

Lagadec L.-R., Patrice P., Chazelle B., Braud I., Dehotin J., Hauchard E., Breil P. 2016b. Description and evaluation of a surface runoff susceptibility mapping method. Journal of Hydrolgy. Vol. 541 p. 495-509.

LAVERNE G. 2013. Comment utiliser la méthode de cartographie du ruissellement IRIP pour améliorer la prise en compte du ruissellement dans l'analyse des risques ferroviaires? [How to use the IRIP runoff mapping method to improve the consideration of runoff in the rail risk analysis?] SNCF Projets Systèmes Ingénierie. Lyon, France. IRSTEA Hydrology-Hydraulic Research Unit pp. 78

Mokhtari E.H., Remini B., Hamoudi S.A. 2016. Modelling of the rain-flow by hydrological modelling software system HEC-HMS - watershed's case of wadi Cheliff-Ghrib, Algeria. Journal of Water and Land Development. No. 30 p. 87-100. DOI 10.1515/jwld-20160025 .

Nouaceur Z., Laignel B., TurKi I. 2013. Changements climatiques au Maghreb: vers des conditions plus humides et plus chaudes sur le littoral algérien? [Climate change in the Maghreb: towards wetter and warmer conditions on the Algerian coast?]. Géographie Physique et Environnement. Vol. 7. No. 1 p. 307-323.

REMENIERAS G. 1976. L'hydrologie de l'ingénieur [The hydrology of the engineer]. $2^{\text {nd }}$ ed. Paris. Eyrolles pp. 456.

Sghara N. 2013. Protection de la ville de Béni-Ounif (Béchar) contre les inondations: Application de logiciels HEC-HMS et HEC-RAS [Protection of the city of Béni-Ounif (Béchar) against floods: Software application HEC-HMS and HEC-RAS]. MSc Thesis. Algiers. USTHB pp. 167.

SKHAKHFA I.D., OUERDACHI L. 2016. Hydrological modelling of Wadi Ressoul watershed, Algeria, by HECHMS model. Journal of Water and Land Development. No. 31 p. 139-147. DOI 10.1515/jwld-2016-0045.

Tran H.B., La NGOC Q., Le ThI T.H., Tran T.D.H., DEBARATI G.-S. 2011. Impacts of flood on health: epidemiologic evidence from Hanoi, Vietnam. Global Health Action, 4: 6356. DOI 10.3402/gha.v4i0.6356.

USGS 2016. Digital elevation model [online]. United States Geological Survey. [Access 14.11.2016]. Available at: https://gdex.cr.usgs.gov/gdex

ZounOui A. 2008. Evaluation de l'aptitude culturale pour le blé dur (Triticum durum Desf. var MBB) et l'orge (Hordeum vulgare L. var. Saida) des terres des Hautes Plaines Constantinoises [Evaluation of the cultural suitability for durum wheat (Triticum durum Desf. Var MBB) and barley (Hordeum vulgare L. var Saida) in the High Constantine Plains]. PhD Thesis. Algiers. National Institute of Agronomy El Harrach pp. 322. 


\section{Dali NAOUEL, Derradji ZOUINI, Pascal BREIL}

Zarządzanie ryzykiem powodziowym w zlewni Gareat El Taref na wyżynach Constantine w północnowschodniej Algierii z wykorzystaniem metody IRIP

\section{STRESZCZENIE}

Termin powódź jest często kojarzony z wezbraniem rzeki lub powodziami sztormowymi. Powodzie spływowe są rzadziej brane pod uwagę, a ich znajomość i kontrola zjawiska są niewystarczające. W pracy przedstawiono system informacji geograficznej iRIP (Fr. Indicateur de Ruissellement Intense Pluvial), który jest nowym narzędziem do mapowania powodzi i może służyć jako wsparcie procesów decyzyjnych w odniesieniu do zlewni Gareat El Taref (północnowschodnia Algieria) poprzez identyfikowanie obszarów powstawania, przemieszczania i akumulacji wód powodziowych.

W wyniku prac uzyskano mapy przedstawiające potencjalne możliwości generowania spływów o różnej dynamice: mapę tworzenia spływów, mapę przemieszczania spływów, mapę akumulacji spływów i mapę powodzi spływowych.

Wizualna symulacja mapy ryzyka powodziowego wskazuje, że obszary o znaczącym ryzyku obejmują gminy: Khenchela, Oum El Bouaghi, Ain El Beida i F'kirina oraz drogi łączące Khenchela z Ain El Beida i z Oum El Bouaghi.

Miasto Khenchela jest narażone na duże ryzyko powodzi spływowej. Rozwiązania proponowane przez władze sprowadzają się do budowy kanału i są niewystarczające, ponieważ północ miasta nadal pozostaje narażona na ryzyko, a ponadto duże obszary powstawania powodzi usytuowane są między kanałem a miastem.

Prawdopodobnie pomocne byłyby zachęty dla rolników, aby wprowadzali pewne praktyki rolnicze, które są elementem zrównoważonego zarządzania ryzykiem powodzi spływowych.

Słowa kluczowe: $i R I P$, Khenchela, ryzyko powodziowe, spływ, zarzadzanie powodzia 